International Journal of Current Advanced Research

ISSN: O: 2319-6475, ISSN: P: 2319 - 6505, Impact Factor: SJIF: 5.995

Available Online at www.journalijcar.org

Volume 6; Issue 5; May 2017; Page No. 3728-3730

DOI: http://dx.doi.org/10.24327/ijcar.2017.3730.0357

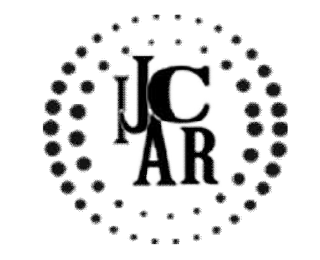

Research Article

\title{
PREVALENCE AND CONSEQUENCES OF PRETERM ADMISSIONS AT THE NEONATAL INTENSIVE CARE UNIT OF TERTIARY CARE CENTRE IN SOUTH INDIA: A RETROSPECTIVE STUDY
}

\section{Ankur Gupta1 ${ }^{1}$, Dhrithiman Shetty ${ }^{1}$ and Kamath K Madhava ${ }^{2}$}

${ }^{1}$ Department of Paediatrics K.s.Hegde Medical College and Hospital, Deralakatte, Mangalore, Karnataka 575018

2Department of Pediatrics, Adichunchungiri Institute of Medical Sciences, Mandya District, Karnataka, India

\section{A R T I C L E I N F O}

Article History:

Received $17^{\text {th }}$ February, 2017

Received in revised form $26^{\text {th }}$ March, 2017

Accepted $7^{\text {th }}$ April, 2017

Published online $28^{\text {th }}$ May, 2017

Key words:

Preterm, Risk factors, Gestational age

\begin{abstract}
A B S T R A C T
Background: Preterm babies have increased risk of morbidity and mortality which is inversely related to both gestational age and birth weight.

Objectives: To study the prevalence and consequences of preterm neonates admissions in NICU, K.S. Hegde hospital Mangalore as well as their morbidity pattern and risk factors for preterm birth.

Methodology: All preterm babies admitted from March 2014 to February 2016 were retrospectively studied. Information obtained included gestational age at birth, gender, risk factors for preterm birth, medical problems during admission and outcome.

Results: Preterm admissions constituted $14 \%$ of the total admissions with a male to female ratio of $0.84: 1$.The commonest risk factor for preterm birth was premature rupture of membranes $(40 \%)$ followed by Previous preterm delivery and Hypertension in pregnancy $(10 \%)$ and multiple pregnancy $(8 \%)$ respectively. The commonest medical conditions were Neonatal jaundice (36\%) followed by respiratory distress syndrome in $27(27 \%)$ and sepsis in $15(15 \%)$. The case fatality rate was highest in neonates with neonatal seizure and Asphyxia (50\%) followed by respiratory problems (30\%) and birth defects (25\%). The overall survival rate was $95 \%$ and was significantly higher in the mild preterm category compared to the very preterm and extremely preterm births.

Conclusion: Preterm births constituted a significant percentage of neonatal admissions with the case fatality being highest among those with neonatal seizure and Asphyxia and survival rate of $95 \%$.
\end{abstract}

Copyright $(2017$ Ankur Gupta et al. This is an open access article distributed under the Creative Commons Attribution License, which permits unrestricted use, distribution, and reproduction in any medium, provided the original work is properly cited.

\section{INTRODUCTION}

Preterm birth is defined as child birth occurring at less than 37 completed weeks and is a major determining factor of neonatal morbidity and mortality with long term consequences. $^{1,2}$ Preterm deaths constitute $28 \%$ of the 4 million annual new born deaths with $99 \%$ of these deaths happening in developing countries worldwide. ${ }^{3}$ The World Health Organization (WHO) estimated $9.6 \%$ of all births worldwide to be preterm. ${ }^{4}$ Causative factors of preterm birth include medical conditions of the mother or fetus, genetic causes, environmental exposure, and socio-economic factors. ${ }^{5}$ Pennell et al suggested that $45 \%$ to $50 \%$ of preterm births are idiopathic, $30 \%$ are due to preterm rupture of membranes and another $15 \%$ to $20 \%$ result from maternal medical problems or elective preterm deliveries. ${ }^{6}$ Factors influencing success in the management of prematurity include level of perinatal care, gestational age at birth, gender, resource availability and adequate and well trained personnel. ${ }^{7}$

*Corresponding author: Ankur Gupta Department of Paediatrics K.s.Hegde Medical College and Hospital, Deralakatte, Mangalore, Karnataka 575018
Preterm infants compared to term infants will have more difficulty with feeding, hypoglycemia, neonatal jaundice, hypothermia, apnoea of prematurity, respiratory distress and sepsis. ${ }^{8}$ It is important to carry out neonatal audit regularly as disease patterns vary from place to place and from time to time in the same place. ${ }^{9}$ The present study was therefore carried out at the NICU, K.S.Hegde hospital mangalore ,Karnataka with the goal of determining the risk factors for preterm births as well as the prevalence and outcome of preterm admissions in order to improve survival of this vulnerable group.

\section{MATERIALS AND METHODS}

A retrospective study was conducted in the Department of Paediatrics NICU, K.S.Hegde medical college and hospital, Deralakatte, Mangalore, karnataka where in numbers of all preterm admissions over the 24 month period (March 2014 to february 2016) were obtained. All preterm babies in the NICU of the K.S.Hegde hospital born at gestational ages of less than 37 completed weeks of gestation were included into the study. Information obtained from the hospital records include gestational age at birth, place of birth, gender, birth weight, 
risk factors for preterm birth, medical problems during the period of admission and outcome. The gestational ages at birth were calculated using the first date of the mother's last menstrual period. The preterm babies were classified into 3 main categories according to gestational age at birth with those born from 32 to 36 weeks categorized as mild preterms, 28 to 31 weeks very preterm and less than 28 weeks classified as extremely preterm for birth.

\section{Data Analysis}

Data was entered into an excel spreadsheet and was analyzed using SPSS version 22. Test of significance between proportions was determined using Chi-square at a $95 \%$ confidence interval with a $\mathrm{p}$ value of less than 0.05 considered statistically significant.

\section{RESULTS}

\section{General Characteristics}

During this study period, 720 babies were admitted in NICU of K.S. Hegde hospital of which 101 (14\%) were preterm. There were 46 males and 55 females with a male to female ratio of $0.84: 1$. Their gestational age at birth ranged from 26 to 36 weeks +6 days. $23(23 \%)$ of the neonates were born at 34 weeks gestation followed by $28(28 \%)$ born at 35 weeks gestation. Most of the neonate, 99 (98\%) were born between gestational ages of 26 and 36 weeks. Their birth weights ranged from $800 \mathrm{~g}$ to $2600 \mathrm{~g}$.

Table 1 Clinical outcome as per gestational age

\begin{tabular}{ccccc}
\hline $\begin{array}{c}\text { Gestational } \\
\text { age at } \\
\text { birth (weeks) }\end{array}$ & $\begin{array}{c}\text { Total } \\
\text { number } \\
\mathbf{( \% )}\end{array}$ & Discharged & Died & $\begin{array}{c}\text { Survival } \\
\text { rate } \\
\mathbf{( \% )}\end{array}$ \\
\hline 26 & 1 & - & 1 & 0 \\
28 & 3 & 1 & 2 & 33 \\
29 & 3 & 1 & 2 & 33 \\
30 & 1 & - & 1 & 0 \\
31 & 2 & 2 & 0 & 100 \\
32 & 8 & 6 & 2 & 75 \\
33 & 8 & 8 & 0 & 100 \\
34 & 22 & 20 & 2 & 91 \\
35 & 26 & 26 & 0 & 100 \\
$36+6$ days & 27 & 27 & 0 & 100 \\
\hline
\end{tabular}

\section{Risk Factors for Preterm Birth}

The commonest risk factor for preterm birth was premature rupture of membranes (40\%) followed by Previous preterm delivery (12\%) and Hypertension in pregnancy (11\%) and multiple pregnancy $(8 \%)$ respectively.

Table 2 Risk factors for preterm delivery

\begin{tabular}{ccc}
\hline Risk factor & Number & Percentage \\
\hline Preterm rupture of membranes & 40 & 40 \\
Previous preterm delivery & 10 & 10 \\
Hypertension in pregnancy & 10 & 10 \\
Multiple pregnancy & 8 & 8 \\
Idiopathic & 7 & 7 \\
Ante-partum hemorrhage & 6 & 6 \\
Gestational Diabetes mellitus & 4 & 4 \\
Maternal febrile illness & 4 & 4 \\
Teenage mother & 4 & 4 \\
Maternal chorioamnionitis & 4 & 4 \\
Birth defect & 3 & 3 \\
\hline
\end{tabular}

\section{Morbidity and Mortality Pattern}

The commonest medical conditions were Neonatal jaundice (36\%) followed by respiratory distress syndrome in $27(27 \%)$ and sepsis in $15(15 \%)$. The case fatality rate was highest in neonates with seizures and Asphyxia (50\%) followed by respiratory problems $(30 \%)$ and birth defects $(25 \%)$. The overall survival rate was $95 \%$.

Table 3 Morbidity and Mortality Pattern

\begin{tabular}{ccccc}
\hline Problem & Number & $\begin{array}{c}\text { Percentage } \\
\mathbf{n}=\mathbf{1 0 1}\end{array}$ & $\begin{array}{c}\text { Number } \\
\text { who died }\end{array}$ & $\begin{array}{c}\text { Case fatality } \\
\text { rate (\%) }\end{array}$ \\
\hline Neonatal Jaundice & 36 & 36 & 0 & 0 \\
Respiratory distress & 27 & 27 & 8 & 30 \\
syndrome & 15 & 15 & 1 & 7 \\
Sepsis & 4 & 4 & 2 & 50 \\
Asphyxia & 4 & 4 & 0 & 0 \\
Apnea of prematurity & & 6 & 0 & 0 \\
Congenital heart & 6 & 2 & 1 & 50 \\
disease & 2 & 4 & 0 & 0 \\
Seizures & 4 & 4 & 1 & 25 \\
Hypoglycemia & 4 & & & \\
Birth defect & 4 & &
\end{tabular}

Clinical Outcome: The overall survival rate was $95 \%$. The survival rate was significantly higher in the mild preterm category compared to the very preterm and extremely preterm for birth categories with $p$ value $<0.001$.

Table 4 Survival rate according to degree of prematurity

\begin{tabular}{cccccc}
\hline Category & $\begin{array}{c}\text { Total } \\
\text { number }\end{array}$ & $\begin{array}{c}\text { Percentage of } \\
\text { total } \\
\mathbf{n}=\mathbf{1 0 1}\end{array}$ & $\begin{array}{c}\text { Number } \\
\text { who } \\
\text { survived }\end{array}$ & $\begin{array}{c}\text { Survival } \\
\text { rate \% }\end{array}$ & p value \\
\hline $\begin{array}{c}<28 \text { weeks } \\
28 \text { to 31 weeks }+6\end{array}$ & 1 & 1 & 0 & 0 & $<0.001$ \\
$\begin{array}{c}\text { days } \\
32 \text { to 36 weeks }+6\end{array}$ & 9 & 9 & 5 & 56 & \\
days & 91 & 90 & 91 & 100 & \\
\hline
\end{tabular}

\section{DISCUSSION}

In present study preterm admissions constituted $14 \%$ of all admissions at NICU of K.S. Hegde hospital. This is less than the $16.4 \%$ reported by McGil Ugwu et al. ${ }^{10}$

The reason for this disparity is not clear but can be due to difference in the incidence of preterm birth in the various parts of world due to geographical and ethnic variations in study populations.

There were more preterm females than males in the present study similar to the study by McGil Ugwu et al and Zeleke et $a l .{ }^{10,11}$ The commonest risk factor for prematurity was preterm rupture of membranes. Multiple pregnancy ranked fourth as a risk factor for preterm delivery in the present study. Etuk et al and attah et al have also reported multiple pregnancy as a risk factor for preterm delivery. ${ }^{12,13}$ The popular hypothesis is that multiple pregnancy leads to over distension of the uterus which may stimulate premature uterine contractions resulting in preterm delivery. ${ }^{14,15}$ Rate of preterm delivery was significantly higher in the hypertensive mothers compared to the mothers with normal blood pressure. ${ }^{16,17,18}$ Hypertensive disorders in pregnancy ranked third risk factor for preterm birth in the present study. Hypertension in pregnancy is believed to predispose to acute or chronic utero-placental insufficiency resulting in antepartum and perinatal hypoxia with associated adverse outcomes of which preterm delivery is one. ${ }^{19}$ The commonest morbidity in the babies in present study was Neonatal Jaundice followed by respiratory distress syndrome and sepsis. This is similar to reports by Khan et al who reported jaundice and sepsis as the commonest morbidities in preterm neonates. ${ }^{20}$ Onalo et al also reported jaundice as the commonest morbidity in preterm babies. ${ }^{21}$ This highlights the importance of infection control in the 
management of preterm babies who are a high risk group for sepsis because of their immature immune system. ${ }^{22}$ In the present study,' overall survival rate was $90 \%$ with the survival rate improving with increasing gestational age.

\section{CONCLUSION}

Preterm deliveries constituted a significant percentage of neonatal admissions at the NICU, K.S. Hegde hospital, mangalore, karnataka with the case fatality being highest among those with Birth asphyxia, Birth defect and Respiratory problems, survival rate of $90 \%$. There is an urgent need for greater awareness of increased risk of preterm morbidity in medical specialities.

\section{Acknowledgements}

We would like to thank the department of pediatrics and NICU of K.S. Hegde medical college and hospital for their active participation and constant support.

\section{References}

1. Huddy, C.L., Johnson, A. and Hope, P.L. (2001) Educational and Behavioral Problems in Babies of 32 35 Weeks Gestation. Archives of Disease in Childhood. F et al and Neonatal Edition, 85, 23-28.

2. Wang, M.L., Dorer, D.J., Fleming, M.P. and Catlin, E.A. (2004) Clinical Outcomes of Near-Term Infants. Pediatrics, 114, 372-374.

3. Federal Ministry of Health (2011) Saving Newborn Lives in Nigeria. Newborn Health I the Context of the Integrated Maternal, Newborn and Child Health Strategy. Revised 2nd Edition, 2011

4. Beck, S., Wojdyla, D., Say, L., betran, A.P., Merialdi, M., Requejo, J.H., et al. (2010) The Worldwide Incidence of Preterm Birth: A Systematic Review of Maternal Mortality and Morbidity. Bulletin of the World Health Organization, 88, 31-38.

5. Goldenberg, R.L., Culhane, J.F., Iams, J.D. and Romero, R. (2008) Epidemiology and Causes of Preterm Birth. Lancet, 371, 75-84.

6. Pennell, C.E., Jacobsson, B., Williams, S.M., Buus, R.M., Muglia, L.J. and Dolan, SM. (2007) Genetic Epidemiologic Studies of Preterm Birth: Guidelines for Research. American Journal of Obstetrics \& Gynecology, 196, 107-118.

7. Baron, L., Hodgaman, J.E. and Pavlova, Z. (1999) Causes of Death in the Extremely Low Birth Weight Infant. Pediatrics, 103, 446-451.

8. Engle, W.A., Tomashek, K.M., Wallman, C. and the Committee of Fetus and Newborn (2007) "LatePreterm" Infants: a Population at Risk. A Clinical Report. Pediatrics, 120, 1390-1401.

9. Abbasi, K.A. (1995) Neonatal Disease Profile in Larkana before and after Establishment of Neonatal Ward. Journal Pakistan Medical Association, 45, 235236.
10. McGil Ugwu, G.I. (2012) Pattern of Morbidity and Mortality in the Newborn Special Care Unit in a Tertiary Institution in the Niger Delta Region of Nigeria: A Two Year Prospective Study. Global Advanced Research Journal of Medicine and Medical Sciences, 1, 133-138

11. Zeleke, B.M., Zelalem, M. and Mohammed, N. (2012) Incidence and Correlates of Low Birth Weight at a Referral Hospital in North-West Ethiopia. The Pan African Medical Journal, 12, 4.

12. Etuk, S.J., Etuk, I.S. and Oyo Ita, A.E. (2005) Factors Influencing the Incidence of Preterm Birth in Calabar, Nigeria. The Journal of Physiological Sciences, 20, 6368.

13. Omole-Ohonsi, A. and Attah, RA. (2012) Risk Factors of Preterm Deliveries at Aminu Kano Teaching Hospital, Kano, Nigeria. South Asian Journal of Management Sciences, 1, 3-10

14. Wood, N.S., Marlow, N., Costeloe, K., Gibson, A.T. and Wilkinson, A.R. (2000) Neurological and Developmental Disability after Extreme Preterm Birth. EPICure Study Group. The New England Journal of Medicine, 343, 378-384.

15. Gyetvai, K., Hannah, M.E., Hodnett, E.D. and Ohisson, A. (1999) Tocolysis for Preterm Labour: A Systematic Review. Obstetrics \& Gynecology, 94, 869-877.

16. Shrestha, S., Dangol Singh, S., Shrestha, M. and Shrestha, R.P.B. (2010) Outcome of Preterm Babies and Associated Risk Factors in a Hospital. Journal of Nepal Medical Association, 49, 286-290.

17. Charearnsutsiri, R. (2004) Outcomes of Very Low Birth Weight Infants at Prapokklao Hospital in the First Four Years of the New Millennium. The Journal of Prapokklao Hospital Clinical Medical Education Center, 21, 175-183.

18. Onyiriuka, A.N. and Okolo, A.A. (2007) Neonatal Morbidity Pattern in Infants Born in Benin City to Nigerian Mothers with Hypertensive Disorders in Pregnancy. Nigerian Journal of Clinical Practice, 10, 294-299.

19. Ferrer, R.L., Sibai, B.M., Mulrow, C.D., Chiquette, E., Stevens, K.R. and Cornell, J. (2000) Management of Mild Chronic Hypertension during Pregnancy: A Review. Obstetrics \& Gynecology, 96, 849-860.

20. Khan, M.R., Maheshwari, P.K., Shamim, H., Ahmed, S. and Ali, S.R. (2012) Morbidity Pattern of Sick Hospitalized Preterm Infants in Karachi, Pakistan. Journal of Pakistan Medical Association, 62, 386-388.

21. Onalo, R. and Olateju, K.E. (2013) Trend and Seasonality in Admissions and Outcome of Low Birth Weight Infants in Gwagalada Abuja, Nigeria. International Journal of tropical disease \& Health, 3, 190-198.

22. McGuire, W., Clerihew, L. and Fowlie, P.W. (2004) Infection in the Preterm Infant. British Medical Journal, 329, 1277-1280.

\section{How to cite this article:}

Ankur Gupta et al (2017) 'Prevalence And Consequences Of Preterm Admissions At The Neonatal Intensive Care Unit Of Tertiary Care Centre In South India: A Retrospective Study', International Journal of Current Advanced Research, 06(05), pp. 3728-3730. DOI: http://dx.doi.org/10.24327/ijcar.2017.3730.0357 